\title{
ANTIHYPERURICEMIA ACTIVITY OF ETHANOL EXTRACT AND FRACTIONS OF AZADIRACHTA INDICA LEAF IN VIVO AND MECHANISM OF ACTION OF ACTIVE FRACTIONS IN VITRO
}

\author{
Deden Winda Suwandi ${ }^{\star}$, Anas Subarnas ${ }^{2}$, Sri Adi Sumiwi \\ ${ }^{1}$ Department of Pharmacy, Faculty of Mathematics and Natural Sciences, \\ Universitas Garut, Jati Street No. 42B, Tarogong Kaler, Garut, West Java, 44151, \\ Indonesia \\ 2Department of Pharmacology and Clinical Pharmacy, Faculty of Pharmacy, \\ Universitas Padjadjaran, Jatinangor Highway, Km 21, Jatinangor, Sumedang, \\ West Java, 45363, Indonesia \\ ${ }^{*}$ Corresponding author: Deden Winda Suwandi (deden@uniga.ac.id) \\ | Received: 11 June 2021

\begin{tabular}{|c|c|c|}
\hline ARTICLE HISTORY \\
\hline Revised: 23 July 2021
\end{tabular} \\ |Accepted: 29 July 2021
}

\begin{abstract}
Azadirachta indica, A.,Juss is a medicinal plant that is used traditionally for some disease, especially its leaves to treat a rheumatic diseases and lower blood uric acid levels. This study was carried out to examine antihyperuricemia activity of ethanol extract, water fraction, ethyl acetat fraction and $n$-hexane fraction of the A. Indica leaves in male mice of Swiss-Webster strain. Extract and fraction doses used were 250 and $500 \mathrm{mg} / \mathrm{kg}$ of body weight and the doses of allopurinol as a standard drug was 13 $\mathrm{mg} / \mathrm{kg}$ of body weight. The tests were conducted on mice suffering from hyperuricemia induced by potassium oxonat at adose of $300 \mathrm{mg} / \mathrm{kg}$ of body weight intraperitoneally and chicken liver juice orally. Measurement of blood uric acid levels were performed using an Easy Touch ${ }^{\circledR}$ every hour for 4 hours after being given test preparations. The results showed that the ethanol extract and the fractions lowered blood uric acid levels in the same way as allopurinol did. The n-hexane fractions at the all doses showed the highest activity, followed by ethanol fraction, and water fraction at the dose of 250 $\mathrm{mg} / \mathrm{kg}$ at the 4th hour. These results illustrated that the $A$. Indica leaves might be potential to be used as antihyperuricemia. The active compounds which possibly reduce blood uric acid levels in mice are believed to be flavonoid or polyphenolic compounds because they are reported to be able to inhibit the action of the xanthine oxidase enzyme that converts purines into uric acid. Then, the most active fraction, $n$ hexane fraction, was tested for its inhibitory activity on xanthine oxidase enzyme to determine its mechanism of action. The results showed that the n-hexane fraction, like allopurinol, inhibited uric acid biosynthesis through inhibiting the activity of xanthine oxidase enzyme with the $\mathrm{IC}_{50}$ value of $132 \mu \mathrm{g} / \mathrm{mL}$ lower than that of allopurinol $\mathrm{IC}_{50}$ $58.35 \mu \mathrm{g} / \mathrm{mL}$.
\end{abstract}

Key words: $A$. indica leaves, antihyperuricemia, chicken liver juice, potassium oxonat, xanthine oxidase. 


\section{Introduction}

Hyperuricemia is a condition characterized by excessive levels of uric acid in the blood as the result of exceeding production of uric acid in the body from the normal levels or caused by the intake of foods rich in nucleic acids such as intestines, grains, seafood, and yeast foods which is a source of high purines. Purines are precursors for the biosynthesis of uric acid by catalyzing the enzyme xanthine oxidase. ${ }^{1,2}$

Therapy of hyperuricemia can be performed by reducing blood uric acid levels through reducing the production of uric acid or increasing the excretion of uric acid by the kidneys. Blood uric acid production can be inhibited or decreased by drugs by means of inhibiting the activity of the xanthine oxidase enzyme, such as Allopurinol, while uric acid excretion can be increased by uricosuric drugs through inhibition of renal tubular reabsorption such as Probenicide. ${ }^{3}$

In addition to synthetic drugs, which are commonly used clinically, there are many alternative medicines from nature such as Azadirachta indica leaf which has been traditionally used to treat rheumatic diseases and reduce blood uric acid levels ${ }^{4}$

Azadirachta indica was firstly found in Indonesia since 1500 and Java Island was the main zone that cultivated this plant. This plant grows particularly in West Java, East Java, and Madura which have altitude up to $300 \mathrm{~m}$ above sea level and dry places. The leaves of $A$. indica have been used as drugs for rheumatism and hypertension. ${ }^{4}$

In this study, in vivo testing of the antihyperuricemic activity of Azadirachta indica leaves was carried out in experimental white mice and continued with testing its mechanism of action as an antihyperuricemia in vitro. In vivo testing was carried out on experimental white mice with hyperuricemia after being given a uric acid inducer. In vitro testing was carried out using the method of inhibiting the activity of the xanthine oxidase enzyme.

\section{Materials and Methods}

\section{Materials}

The plant material used in this study was Azadirachta indica leaf (A. indica leaf). The plant material was taken in Subang Regency, West Java. This plant was authenticated at the Laboratory of Herbarium Bandungense, School of Life Science and Technology, Bandung Institute of Technology, Indonesia. The material used in the maceration process is $70 \%$ ethanol. Phytochemical screening of extracts used were Mayer reagent, Dragendorff, chloroform, ether, magnesium powder, isoamyl alcohol, $2 \mathrm{~N} \mathrm{HCl}$, Lieberman-Burchard reagent, $5 \% \mathrm{KOH}$ solution, $\mathrm{FeCl} 3,10 \%$ vanillin in concentrated $\mathrm{H}_{2} \mathrm{SO}_{4}$, and $1 \%$ gelatin. Chemicals used in testing antihyperuricemia activity or xanthine oxidase inhibitor activity include potassium oxonate, chicken liver juice, allopurinol, aquadest and PGA. The equipment used were Syringe $1 \mathrm{~mL}$, oral probe for mice, mouse scales, uric acid measuring instrument (Easy touch ${ }^{\circledR}$ ), glassware commonly used in chemistry laboratories, X7375-10G xanthine oxidase kit (Sigma-aldrich), and spectrophotometry.

\section{Methods}

\section{Extract and fraction preparation}

Dried leaves of Azadirachta indica $(1 \mathrm{~kg})$ were powdered and extracted with ethanol $70 \%(3 \times$, each $24 \mathrm{~h})$ at room temperature to produce a diluted ethanol extract. Then it was filtrated with flannel material and filter paper followed by the solvent. Itwas then 
Halaman 150-159

evaporated in the rotary evaporator (Buchi Rotavapor® type of R-120) under reduced pressure at $50^{\circ} \mathrm{C}$ to get a concentrated extract. The extract obtained was then fractionated using n-hexane, ethyl acetate and water as solvents to obtain n-hexane, ethyl acetate and water fractions.

\section{Phytochemical screening}

Phytochemical screening was carried out on thick extracts to determine the presence of secondary metabolite compounds such as alkaloids, flavonoids, saponins, tannins, quinones and teroids/triterpenoids.

\section{Pharmacological assays}

\section{In Vivo antihyperuricemic activity study}

Mice were divided into a control group and a test group, 5 mice for each group. The control group as a negative control group was given an inducer of potassium oxonate at a dose of $300 \mathrm{mg} / \mathrm{kg}$ bw plus chicken liver juice and a carrier. A positive control group consisting of mice was also given an inducer of potassium oxonate $(300 \mathrm{mg} / \mathrm{kg})$ plus chicken liver juice and allopurinol (13 mg/kg bw) as a standard antihyperuricemic agent. Mice as the test group were given an inducer of potassium oxonate $(300 \mathrm{mg} / \mathrm{kg})$ plus chicken liver juice and suspension of ethanol extract, water fraction, ethyl acetate fraction and $\mathrm{n}$-hexane fraction of $A$. indica leaf $(250$ and $500 \mathrm{mg} / \mathrm{kg}$ ). Experimental animals were fasted for approximately 18 hours prior to testing, but were still given water. Before being treated, all experimental animals were measured blood uric acid levels as initial (normal) levels. Then the experimental animals were made hyperuricemic by giving potassium oxonate $300 \mathrm{mg} / \mathrm{kg}$ intraperitoneally and chicken liver juice orally. One hour later the experimental animals were drawn blood to measure uric acid levels. Furthermore, the experimental animals were given a suspension of the test preparation orally. Uric acid levels in the blood of experimental animals were measured at 1, 2, 3, and 4 hours after administration of the test preparation. Mice blood sampling was done by injuring the tail of the mice. Uric acid levels were measured using the Easy Touch ${ }^{\circledR}$ mechine. ${ }^{5}$

The data were statistically analyzed using analysis of variance with a $95 \%$ confidence level followed by a further test of Least Significant Differences (LSD) which was carried out on differences in uric acid levels in each treatment group.

\section{In vitro xanthine oxidase inhibition study}

The method of determining xanthine oxidase inhibition is based on the research method written by Azmi, et al., (2012). First of the all prepare the test substance, comparison (positive control) and negative control. This is done by comparing the absorbance of uric acid formed between the test solution (xanthine + test sample + xanthine oxidase) with the absorbance of the negative control (xanthine + xanthine oxidase) and the absorbance of the positive control (xanthine + allopurinol + xanthine oxidase). Then it is measured by spectrophotometry at a wavelength of $295 \mathrm{~nm}$. Allopurinol $(100 \mathrm{~g} / \mathrm{mL})$ was used as a comparison for the xanthine oxidase inhibition test. The test solution consisted of $300 \mu \mathrm{L}$ of $50 \mathrm{mM}$ sodium phosphate buffer $(\mathrm{pH} 7.5)$, $100 \mu \mathrm{L}$ of the test solution in aquadest or DMSO, $100 \mu \mathrm{L}$ of enzyme solution $(0.2$ units $/ \mathrm{mL}$ of xanthine oxidase in phosphate buffer) and $100 \mu \mathrm{L}$ of aquadest. The above test solution was incubated at $37^{\circ} \mathrm{C}$ for 15 minutes in an incubator. Next, $200 \mu \mathrm{L}$ substrate solution $(0.15 \mathrm{mM}$ xanthine) was added to the test solution and incubated at $37^{\circ} \mathrm{C}$ for $30 \mathrm{~min}$. Then the reaction was stopped by adding $200 \mu \mathrm{L} 0.5 \mathrm{M} \mathrm{HCl}$. The absorbance was measured using a UV/VIS spectrophotometer using a blank enzyme solution in phosphate buffer. As a control used $100 \mu \mathrm{L}$ DMSO containing uric acid. ${ }^{6}$ 
Halaman 150-159

\section{Results}

\section{Material preparation}

The ethanol extract of $A$. indica leaves ( $1 \mathrm{~kg}$ ) was macerated with $70 \%$ ethanol ( $3 \mathrm{x}$ 24 hours) to produce a viscous extract of 112 grams or the yield of the extract was $11.2 \%$. The viscous extract obtained is brownish green in color, has a characteristic smell of sugar and has a bitter taste.

Secondary metabolites in simplicia, extracts and fractions

Phytochemical screening showed that A. indica leaves contained various secondary metabolites, which are shown in Table 1.

Table 1. Secondary metabolites in ethanol extract and fractions of $A$. indica leaf

\begin{tabular}{lccccc}
\hline & \multicolumn{5}{c}{ Result of phytochemical screening } \\
\cline { 2 - 6 } $\begin{array}{l}\text { Secondary } \\
\text { metabolites }\end{array}$ & Simplicia & $\begin{array}{c}\text { Ethanol } \\
\text { extract }\end{array}$ & $\begin{array}{c}\text { Water } \\
\text { Fraction }\end{array}$ & $\begin{array}{c}\text { Ethyl } \\
\text { acetate } \\
\text { fraction }\end{array}$ & $\begin{array}{c}\text { Hexane } \\
\text { Fraction }\end{array}$ \\
\hline Alkaloids & + & + & + & + & + \\
Flavonoids & + & + & + & + & + \\
Tannin & + & + & + & + & + \\
Quinone & - & - & - & - & - \\
Saponins & + & + & + & + & + \\
Steroids/ & + & + & + & + & + \\
Triterpenoids & & & & & \\
\hline Description: $(+)=$ Detected; $(-)=$ Not detected
\end{tabular}

\section{Antihyperuricemia activity in vivo}

The study of antihyperuricemia activity was carried out by observing the decrease in blood uric acid levels in mice after administration of ethanol extract, water fraction, ethyl acetate fraction and $\mathrm{n}$-hexane fraction of Azadirachta indica leaf with doses of 250 and $500 \mathrm{mg} / \mathrm{kg}$ bw (ethanol extract) and 125 and $250 \mathrm{mg} / \mathrm{kg}$ bw (fractions). The test results are shown in Table 2.

Table 2. Average Uric Acid Levels in Mice After Potassium Oxonate Induction (mg/dl)

\begin{tabular}{|c|c|c|c|c|c|c|}
\hline \multirow{2}{*}{$\begin{array}{l}\text { Animals } \\
\text { group } \\
\text { (mg/kg) }\end{array}$} & \multicolumn{6}{|c|}{$\begin{array}{l}\text { Average Uric Acid Levels in Mice After Potassium Oxonate Induction } \\
\text { ( } \mathrm{mg} / \mathrm{dl})\end{array}$} \\
\hline & $\begin{array}{l}\text { before } \\
\text { induction }\end{array}$ & $\begin{array}{c}\text { After } \\
\text { induction }\end{array}$ & 1 hours & 2 hours & 3 hours & 4 Jam \\
\hline Control - & $2 \pm 0.0$ & $6.82 \pm 0.7$ & $7.14 \pm 0.5$ & $5.48 \pm 0.8$ & $4.72 \pm 0.8$ & $4.82 \pm 0.8$ \\
\hline Control + & $2 \pm 0.0$ & $4.14 \pm 0.6$ & $3.9 \pm 0.6^{*}$ & $3.22 \pm 0.6^{*}$ & $2.72 \pm 1.2^{*}$ & $2.96 \pm 1.0$ \\
\hline EEAL 250 & $2 \pm 0.0$ & $5.8 \pm 1.0$ & $3.9 \pm 0.4^{*}$ & & & \\
\hline EEAL 500 & $2 \pm 0.0$ & $5.72 \pm 1.2$ & $3.62 \pm 1.4^{*}$ & $2.94 \pm 1.2^{*}$ & $2.22 \pm 1.4^{*}$ & $2.2 \pm 1.2^{*}$ \\
\hline WFAL 125 & $2 \pm 0.0$ & $6.28 \pm 1.2$ & $6.32 \pm 1.2$ & $4.96 \pm 1.2$ & $4.42 \pm 1.2$ & $0.8 \pm 1.2$ \\
\hline WFAL 250 & $2 \pm 0.0$ & $5.72 \pm 1.4$ & $6.42 \pm 1.8$ & $2.94 \pm 1.8^{*}$ & $3.04 \pm 1.2^{*}$ & $2.24 \pm 1.2^{*}$ \\
\hline EAFAL 125 & $2 \pm 0.0$ & $5.32 \pm 1.2$ & $5.44 \pm 1.6$ & $5.08 \pm 1.2$ & $4.42 \pm 1.2$ & $2.5 \pm 1.6$ \\
\hline EAFAL 250 & $2 \pm 0.0$ & $5.68 \pm 1.2$ & $5.02 \pm 1.2$ & $4.98 \pm 1.4$ & $3.78 \pm 1.2$ & $2.68 \pm 0.8$ \\
\hline HFAL 125 & $2 \pm 0.0$ & $5.76 \pm 1.6$ & $4.5 \pm 1.8$ & $2.46 \pm 1.8^{*}$ & $2.14 \pm 1.8^{*}$ & $1.82 \pm 1.6^{*}$ \\
\hline HFAL 250 & $2+0.0$ & $5.96 \pm 1.2$ & $4.1 \pm 1.8$ & $2.8 \pm 1.6^{\star}$ & $1.92+1.6^{*}$ & $1.9 \pm 1.8^{*}$ \\
\hline
\end{tabular}


*Significantly different from the negative control $(p<0.05)$; Control - = induced + PGA $1 \%$, Control + = allopurinol $13 \mathrm{mg} / \mathrm{kgbb}$. EEAL: ethanol extract of $A$. indica, WFAL:water fraction of A.indica, EAFAL: ethyl acetate fraction of A.indica, HFAL: n-hexane fraction of A.indica.

\section{In vitro xanthine oxidase inhibitor activity}

To see the mechanism of action of the test preparation on decreasing blood uric acid levels, an in vitro test of the xanthine oxidase enzyme inhibitory activity was carried out. The study of xanthine oxidase inhibitory activity was carried out by measuring the absorbance after the test substance was mixed with xanthine and xanthine oxidase enzyme at a temperature of $25^{\circ} \mathrm{C}$ and $\mathrm{pH} 7.5$. The absorbance was measured using UV spectrophotometry at a maximum wavelength of $290 \mathrm{~nm}$. Ethanol extract, water fraction, n-hexane fraction, allopurinol (positive control) $100 \mathrm{ppm}$ and carrier (negative control) were observed for absorbance indicating the concentration of uric acid after mixing the above.

Its activity is calculated by the formula for calculating the activity of xanthine oxidase inhibitors using the equation:

$\%$ xantine oksidase inhibition $=\frac{\text { A.control }- \text { A.test }}{\text { A.control }} \times 100 \%$

A control is the absorbance as xo activity without the test solution and A test is the absorbance of xanthine oxidase activity with the test solution.

Furthermore, the $\mathrm{IC}_{50}$ value was calculated as xanthine oxidase inhibition. $I \mathrm{IC}_{50}$ is calculated using the linear regression equation: $Y=a+b x$. To calculate the $I_{50}$, the concentration variations of the test solution were first made, namely $20 \mathrm{~g} / \mathrm{mL}, 40 \mathrm{~g} / \mathrm{mL}$, $60 \mathrm{~g} / \mathrm{mL}, 80 \mathrm{~g} / \mathrm{ml}, 100 \mathrm{~g} / \mathrm{mL}$ and $120 \mathrm{~g} / \mathrm{mL}$. Inhibitory activity is indicated by $50 \%$ concentration of inhibition, meaning that the concentration of substances that can inhibit xanthine oxidase is $50 \%$. The indication is a decrease in the concentration of uric acid up to $50 \%$.

The inhibitory effect of allopurinol and Azadirachta indica leaf on the activity of the xanthine oxidase enzyme is shown in table 3.

Table 3. Percent Inhibition of Xanthine Oxidase Allopurinol, Extract and Fractions of Azadirachta indica (100 ppm) to $\lambda 290 \mathrm{~nm}$

\begin{tabular}{ccc}
\hline No. & Samples & \% Inhibition to XO \\
\hline 1. & Allopurinol & $84.68 \%$ \\
2. & Ethanol extract & $11.24 \%$ \\
3. & Water fraction & $5.70 \%$ \\
4. & N-hexane fraction & $39.00 \%$ \\
\hline
\end{tabular}

The power of inhibition of a chemical substance is indicated by the concentration of inhibition $\left(\mathrm{IC}_{50}\right)$. Calculations to determine $\mathrm{IC}_{50}$ can be seen in Figures 1 and 2, while the $\mathrm{IC}_{50}$ values of allopurinol and Azadirachta indica leaf $\mathrm{n}$-hexane fraction can be seen in Table 4 below. 


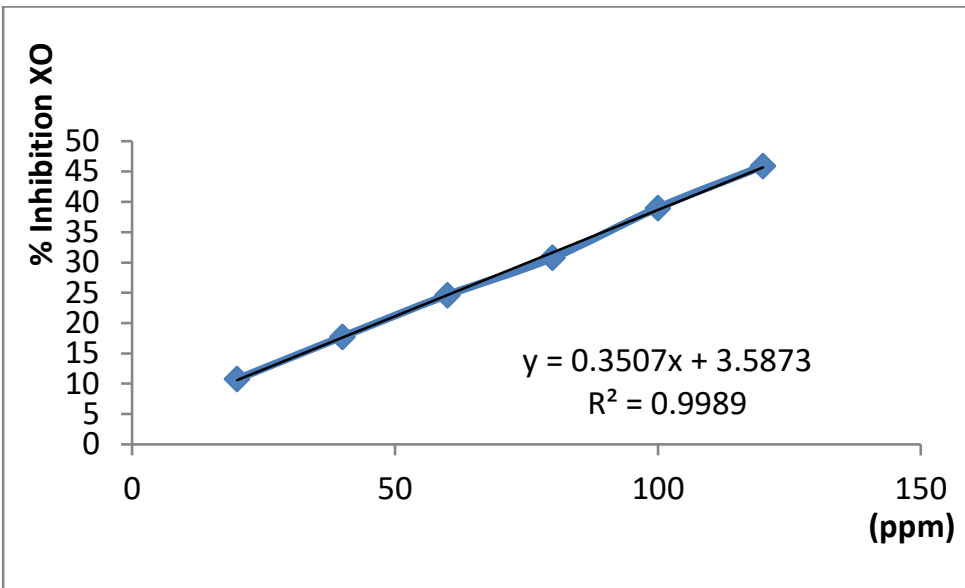

Figure 1. Calibration curve and equation of $n$-hexane fraction

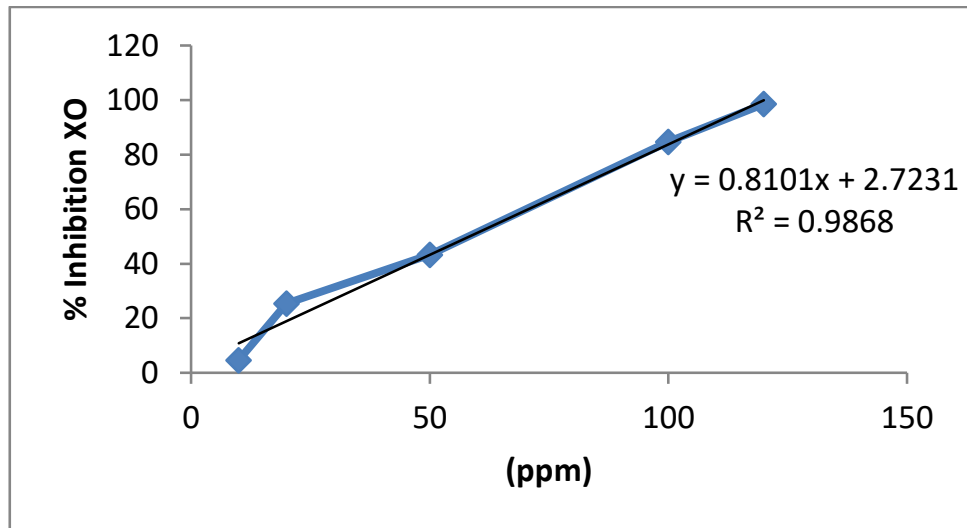

Figure 2. Calibration curve and equation of Allopurinol

Table 4. Value of Inhibition Concentration $\left(\mathrm{IC}_{50}\right)$ of Allopurinol and n-Hexane Fraction at a concentration of $100 \mathrm{ppm}$

\begin{tabular}{ccc}
\hline No. & Sample & $\mathbf{I C}_{50}(\mathbf{p p m})$ \\
\hline 1. & Allopurinol & 58.35 \\
2. & n-hexane fraction & 132 \\
\hline
\end{tabular}

\section{Discussion}

Table 1 shows that in simplicia, ethanol extract and Azadirachta indica leaf fractions contain alkaloids, flavonoids, saponins (except the n-hexane fraction were not detected), tannins, and steroids/triterpenoids were detected, while quinones were not detected in all samples.

The state of hyperuricemia in male mice was obtained by giving potassium oxonate and chicken liver juice. Chicken liver juice is used as an inducer of uric acid because chicken liver is a food that contains high purines. High purines in the blood will stimulate the formation of uric acid by the xanthine oxidase enzyme. ${ }^{7}$ Another inducer used is potassium oxonate which is an inhibitor of the uricase enzyme. In most mammals there is an enzyme uricase which functions to convert uric acid into allantoin which is more soluble in water so that it is excreted with urine. ${ }^{3}$ The inhibition of the 
Halaman 150-159

uricase enzyme by potassium oxonate, uric acid will accumulate and not be eliminated with urine. ${ }^{8}$

The test results were statistically analyzed by analysis of variance (ANOVA) and further test of the Least Significant Difference (LSD) multiple comparison method using the SPSS 16 system. The results of the analysis are shown in Table 2. The data is the average value of blood uric acid levels in mice after being given treatment. In that data shows that the negative control group which was only given intraperitoneal potassium oxonate $(300 \mathrm{mg} / \mathrm{kg} \mathrm{bw})$ and chicken liver juice orally $(0.2 \mathrm{~mL} / 20 \mathrm{~g}$ bw) could significantly increase blood uric acid levels when compared with normal controls. The highest effect was shown at the 1st hour after administration of the inducer with a uric acid level of $7.14 \mathrm{mg} / \mathrm{dL}$ as negative control. This shows that the combination of potassium oxonate and chicken liver juice can effectively induce hyperuricemia.

In the table 2, shows that allopurinol as a standard antihyperuricemia drug commonly used clinically can significantly reduce blood uric acid levels from the 1st hour to the 4th hour compared to the negative control group $(p<0.05)$. The effect of reducing uric acid levels was also shown by the ethanol extract, water and n-hexane fraction, but no to ethyl acetate fraction. The ethanol extract of Azadirachta indica leaves at doses of $500 \mathrm{mg} / \mathrm{kg}$ was effective in reducing blood uric acid levels significantly from the 1 st hour to the 4th hour compared to the negative control $(p<0.05)$.

In the water fraction of Azadirachta indica leaves, a dose of $250 \mathrm{mg} / \mathrm{kg}$ bw had an effectiveness in reducing blood uric acid levels significantly from the 2 nd hour to the 4th hour with significant effect. The n-hexane fraction at the all doses used could significantly reduce blood uric acid levels when compared to the negative control group. The effect of reducing blood uric acid levels occurs at the 2 nd hour to the 4th hour.

Based on the test data above, it can be seen that the $n$-hexane fraction has the strongest activity in reducing blood uric acid levels. This is because the n-hexane fraction may contain active compounds with higher concentrations.

The results showed that the extract and its fractions were quite effective in reducing blood uric acid levels in mice. However, if we look at the reduction in uric acid levels in the blood of male mice, the n-hexane fraction showed the largest reduction compared to allopurinol, ethanol extract or water fraction. This provides an overview of the potential of Azadirachta indica leaves as an antihyperuricemia and gout drug, especially as an $n$-hexane fraction.

The active compounds that play a role in reducing blood uric acid levels in mice are suspected to be flavonoid or polyphenolic compounds because flavonoids or polyphenols are reported to be able to inhibit the action of the xanthine oxidase enzyme that converts purines into uric acid, ${ }^{9}$ or possibly triterpenoid saponins. ${ }^{10}$ Research by Fan, et al., (2014) showed that the triterpenoid saponin, riparsaponin, isolated from Homonoia riparia stems had a significant inhibitory effect on xo enzyme activity in vitro with an $\mathrm{IC}_{50}$ of $11.16 \mathrm{nmol} / \mathrm{mL} .^{10}$

This study showed that both allopurinol and its extracts and fractions were proven to be able to inhibit the occurrence of hyperuricemia in mice induced by potassium oxanate and chicken liver juice. The decrease in the synthesis of uric acid from purines by allopurinol has been known through the inhibition of the enzyme xanthine oxidase, in which xanthine oxidase can oxidize allopurinol to allopurinol and alloxantin can inhibit the formation of xanthine from hypoxanthine and the formation of uric acid from xanthine, respectively. ${ }^{1}$ The mechanism of action of Azadirachta indica leaf extract and fractions in inhibiting hyperuricemia induced by potassium oxanate and chicken liver 
Halaman 150-159

juice is not known with certainty. May be the mechanism is the same as allopurinol or maybe by inhibiting the action of potassium oxanate so that the uricase enzyme present in the body of mice can convert uric acid into allantoin which is more soluble in water or it may work as a uricosuric in which the reabsorption of uric acid in the kidneys is inhibited so that it can increase acid excretion. urate along with urinary excretion. One of the possible mechanisms of action in reducing uric acid levels was investigated through an in vitro xanthine oxidase enzyme activity inhibition test. The results of this experiment can be seen in the next research section. ${ }^{11}$

Xanthine oxidase is one of the enzymes in the human body that is responsible for the synthesis of uric acid from purine substrates. Xanthine oxidase activity can be inhibited by a synthetic chemical compound such as allopurinol. Allopurinol has a structure similar to xanthine which is a substrate for xanthine oxidase in the synthesis of uric acid. In the body, allopurinol will compete with xanthine to bind to the active site of the xanthine oxidase enzyme and react to become oxypurinol which also works as an inhibitor of the xanthine oxidase enzyme. ${ }^{12}$

In addition to synthetic chemical compounds, natural chemical compounds contained in various plant species are reported to contain chemical compounds such as flavonoids, ${ }^{13}$ which are also effective as inhibitors of several enzymes including xanthine oxidase, cyclooxygenase and lipoxygenase. ${ }^{14}$

In table 3 , shows the in vitro study. In the study of xanthine oxidase inhibitory activity, allopurinol $100 \mathrm{ppm}$ was able to inhibit $84.68 \%$. This illustrates that allopurinol which is commonly used clinically effectively inhibits the formation of uric acid by inhibiting the activity of the xanthine oxidase enzyme. The ethanol extract, water fraction, and n-hexane fraction of Azadirachta indica leaf at a concentration of $100 \mathrm{ppm}$ also had activity as a xanthine oxidase inhibitor. The highest activity was shown by the $\mathrm{n}$-hexane fraction of $39.0 \%$. The results of this study support the results of in vivo tests on mice that the Azadirachta indica leaf $\mathrm{n}$-hexane fraction has the highest activity. Based on the results of this in vitro study, it is proven that the ethanol extract and Azadirachta indica leaf fractions can reduce blood uric acid levels through the mechanism of inhibition of xanthine oxidase enzyme activity.

Allopurinol had the highest inhibitory power compared to Azadirachta indica leaves. Allopurinol has an $\mathrm{IC}_{50}$ value of $58.35 \mathrm{ppm}$, meaning that allopurinol has the power to inhibit the conversion of xanthine to uric acid by the xo enzyme up to $50 \%$ of its activity or its uric acid level, which is at a concentration of $58.35 \mathrm{ppm}$. This value is better than the inhibitory power of Azadirachta indica leaf n-hexane fraction which has an $\mathrm{IC}_{50}$ of $132 \mathrm{ppm}$. The suspected compound in the hexane fraction that works best to inhibit the xanthine oxidase enzyme is flavonoid or polyphenolic compounds because this compound are reported to be able to inhibit the action of the xanthine oxidase enzyme that converts purines into uric acid. ${ }^{9}$ This means that the potency of Azadirachta indica leaves in lowering uric acid levels or inhibiting the xanthine oxidase enzyme is lower than allopurinol.

\section{Conclusion}

Based on this research, it can be concluded as follows:

1. Azadirachta indica leaves have antihyperuricemic activity against male mice, especially at a dose of $500 \mathrm{mg} / \mathrm{kg}$ body weight which has an effect starting from the 1st hour after drug administration until with increasing time. It shows a decrease in uric acid levels to blood uric acid levels. Male mice became in normal condition. The best activity was the n-hexane fraction at a dose of $250 \mathrm{mg} / \mathrm{kg} \mathrm{bw}$. 
Halaman 150-159

2. The mechanism of action of Azadirachta indica leaves, especially in the n-hexane fraction, showed activity to reduce uric acid levels through inhibition of the xanthine oxidase enzyme in vitro, with an $\mathrm{IC}_{50}$ value of $132 \mathrm{ppm}$.

\section{References}

1. Katzung BG, Masters SB, Trevor AJ. Basic \& Clinical Pharmacology (Twelf edit; Bertram. G. Katzung, ed.). 2012. Retrieved from https://www.academia.edu/35509985/Basic_and_Clinical_Pharmacology_Katzung _Masters_and_Trevor_.pdf

2. Abdullahi W, Hamzah RU, Jigam AA, Yahya A, Kabiru AY, Muhammad A, Sakpe, S, Adefolalu FS, Isah MC,Kolo MZ. Inhibitory activity of xanthine oxidase by fractions Crateva adansonii, J. of Acute Disease. 2012; 126-129.

3. Gilman AG, Rall TW, Nies AS, Taylor P. Goodman and Gilman's the pharmacological basis of therapeutics, 12th Ed., New York. McGraw-Hill. 2012.

4. Tima MT, Sri Wahyuni dan Murdaningsih, Etnobotani Tanaman Obat Di Kecamatan Nangapanda Kabupaten Ende Nusa Tenggara Timur. J. Penelitian Kehutanan, 2020; Vol. 4 (1): 23-38.

5. Suwandi DW, Perdana F. Antihyperuricemia Activity of Ethanol Extract and Guava Leaf Fractions in Swiss Webster Male, J ilmiah farmako bahari, 2018; Vol. 9; (1), Hal. 36-44.

6. Azmi SMN, Jamal P, Amid A. Xanthine oxidase inhibitory activity from potential Malaysian medicinal plant as remedies for gout International Food Research Journal 19: x-x. 2012.

7. Kristiani RD, Rahayu D, Subarnas A. Aktivitas Antihiperurisemia Ekstrak Etanol Akar Pakis Tangkur (Polypodium feei) Pada Mencit Jantan., Bionatura-Jurnal IImuilmu Hayati dan Fisik. 2013; Vol. 15, (3), 174-177.

8. Sagor MAT, Tabassum N, Potol, MA, Alam MA. Xanthine Oxidase Inhibitor, Allopurinol, Prevented Oxidative Stress, Fibrosis, and Myocardial Damage in Isoproterenol Induced Aged Rats. Oxidative Medicine and Cellular Longevity, 2015, 1-9. https://doi.org/10.1155/2015/478039 12Katzung, B.G., Masters, S.B. \& Trevor, A.J. 2012. Basic \& Clinical Pharmacology, 12 Ed., New York: McGraw-Hill.

9. Hendriani R, Sukandar EY. In Vitro Evaluation of Xanthine Oxidase Inhibitory Activity of Sonchus. 2014; Vol. 6; (2), 2-4.

10. Fan X, Xueqian Z,Lingli y, Xiuhua W,Jing Z. A New Cycloartane-Type Triterpenoid Saponin Xanthine Oxidase Inhibitor from Homonoia riparia Lour, journal molecules. 2014;(19), 13422-13431.

11. Akhmad AR, Abdul M, Berna E. Study of Antioxidant Activity with Reduction of DPPH Radical and Xanthin Oxidase Inhibitor of the Extract of Ruella tuberosa Linn. Leaf, Int. Res. Jour. of Pharm. 2012; Vol. 3; (11), p. 66-70.

12. Bakar FIA, Bakar MFA, Rahmat A, Abdullah N. Anti-gout Potential of Malaysian Medicinal Plants. 2018. 9. https://doi.org/10.3389/fphar.2018.00261.

13. Handayani N, Wartono MW, Murti RK. Identification and Antibacterial Activity Test Of The Mimba Leaf (Azadirachta Indica A. Juss). ALCHEMY jurnal penelitian kimia, 2012; Vol. 8, (1), hal. 57-69. 
Jurnal IImiah Farmako Bahari

Deden Winda Suwandi

Vol. 12; No. 2; Juli 2021

Halaman 150-159

14. Nguyen MT, Awale S, Tezuka Y,Tran QL, Watanabe H, Kadota S. Xanthin Oxidase Inhibitory Activity of Vietnamese Medicinal Plants, Biol. Pharm. Bull. 2004; 27 (9) 1414-1421. 